\title{
WAYS OF COPING AND PSYCHOLOGICAL WELL-BEING IN CANCER PATIENT: A COMPARATIVE STUDY BETWEEN CONCEALED AND UNCONCEALED PATIENTS
}

\author{
Koijam Shantibala Devi', Laishram Jaichand Singh², Naorem Rebika Devi³, Elangbam Priyokumar Singh4 \\ ${ }^{1}$ Assistant Professor, Department of Psychiatry, Jawaharlal Nehru Institute of Medical Sciences (JNIMS), Imphal, Manipur. \\ 2 Professor, Department of Radiology, Regional Institute of Medical Sciences, Imphal. \\ 3Ph. D Scholar, Mizoram University. \\ ${ }^{4}$ M. Phil. Clinical Psychology, Regional Institute of Medical Sciences, Imphal.
}

\begin{abstract}
Persons with cancer have to go through many painful conditions, face with new and challenging situations the illness brought to their life. Subsequently, all must cope with new stressors; in dealing with the changed situation (s) they might feel loss of control over their life events. Moreover, if the patients are involved in treatment process, it may add up more stress. However, at times, patients with advanced cancer also do desire information on risks and prognosis. Therefore, determining ways of coping with challenges in life posed by cancer and also comparing psychological wellbeing between patients who do not know (Concealed group) and who know about the diagnosis (Unconcealed group) will be helpful in developing a better treatment plans for cancer patients.
\end{abstract}

\section{MATERIALS AND METHODS}

A total of seventy six (76) cancer patients visiting Department of Radiotherapy, Regional Institute of Medical Sciences (RIMS), Imphal, during February 2014 to December 2014 were enrolled in this study. The total patients were divided into two groups of equal number i.e. 36 each for concealed and unconcealed groups and both the groups were administered the semi-structured questionnaire, Ways of Coping (Folkman S and Lazarus RS, 1985) and The Psychological Wellbeing Index (Dupuy, 1984) and the data were analysed using SPSS version 20.0.

\section{RESULTS}

Comparison on the patients' ways of coping and also on psychological wellbeing schedule shows no significant difference between the two study groups i.e. concealed and unconcealed groups. Findings on ways of coping subscales are confronting ( $p=.340$ ), distancing $(\mathrm{p}=.928)$, self-control $(\mathrm{p}=.808)$, seeking social support $(\mathrm{p}=.868)$, accepting responsibility ( $\mathrm{p}=.692)$, escape-avoidance $(\mathrm{p}=.941)$, planful problem solving $(\mathrm{p}=.106)$, and positive reappraisal $(\mathrm{p}=.390)$, and relation between the two study groups on psychological wellbeing schedule subscales are anxiety $(p=.513)$, depressed $\operatorname{mood}(p=.700)$, positive wellbeing ( $p=.429)$, self-control $(\mathrm{p}=.571)$, general health $(\mathrm{p}=.947)$, vitality $(\mathrm{p}=.877)$, and global score $(\mathrm{p}=.671)$.

\section{CONCLUSION}

The present study finds no significant difference between the two study groups in ways of coping with stress and the psychological wellbeing.

\section{KEYWORDS}

Coping with Stress, Psychological Wellbeing in Concealed, Psychological Wellbeing in Unconcealed Cancer Patient.

HOW TO CITE THIS ARTICLE: Devi KS, Singh LJ, Devi NR, et al. Ways of coping and psychological well-being in cancer patient: a comparative study between concealed and unconcealed patients. J. Evolution Med. Dent. Sci. 2016;5(63):4448-4453, DOI: $10.14260 /$ jemds/2016/1015

\section{INTRODUCTION}

Cancer is a dreadful and life-threatening illness. It induces numerous stressful situations in all aspects of one's life. Due to the diagnosis of cancer and subsequent treatment plans, cancer patients undergo numerous social, emotional, and psychological distress. ${ }^{1-3}$ As the disease progresses, most of the patient's available resources to deal with the new demands of life-like financial, physical, social, and psychological resources gets diminished. Thus, psychological, physical, financial, and social distress cancer patients go through reduces their psychological well-being on many levels of their life.

Financial or Other, Competing Interest: None.

Submission 30-06-2016, Peer Review 23-07-2016,

Acceptance 30-07-2016, Published 06-08-2016.

Corresponding Author:

Elangbam Priyokumar Singh,

M. Phil. Clinical Psychology,

Regional Institute of Medical Sciences,

Imphal.

E-mail: elangpriyo1@gmail.com

DOI: $10.14260 /$ jemds/2016/1015
Psychological wellbeing, which is conceptualised as the positive and constructive thinking of people about themselves is subjective in nature and includes aspects such as physical functioning, psychological, and social elements. ${ }^{4}$ It also means having good emotional and mental health as basis of quality of life in a particular individual in diverse contexts. ${ }^{5,6}$ From this perspective, psychological wellbeing includes the way people used to evaluate their lives in the present and in the past; so, these assessments cover the emotional reactions of people to events, moods, and judgments related to the way they live their own lives. -8 $^{-8}$ As cancer patient's psychological wellbeing is impoverished, psychological problems like depression and anxiety are often manifested in due course of the illness. ${ }^{9}$

Therefore, effective coping with cancer itself and also with associated stress is crucial for having a good quality of life. As stress is a situation that is appraised by the individual as personally significant and as having demands that exceed the person's resources for coping, coping mechanisms also defer from person to person. 
Lazarus and Folkman (1984) ${ }^{10}$ defines coping as "constantly changing cognitive and behavioural efforts to manage specific external or internal demands that are appraised as taxing or exceeding the resources of a person," and coping has been identified as a critical factor in the mediation of effects of stressful life events on the individual's physical and psychological adaptation. There are two major contrasting approaches to the concept of coping i.e. the traitstyle approach, which conceptualises coping as stable individual dispositions to react in particular ways in certain kinds of situations while the process approach views coping as a multidimensional process, which vanes between and within individuals depending on situational aspects and how the individual appraises the situation. ${ }^{11}$ Generally, coping is of two kinds: problem-focused coping, such as planful problemsolving, to address the problem causing distress using strategies such as information gathering and decision making; and emotion-focused coping to regulate negative emotion using strategies such as distancing, seeking emotional support, and escape-avoidance. ${ }^{12}$

Some authors have considered avoidance-oriented coping (Efforts to avoid a stressful situation by seeking out to other people or by engaging in a substitute task) as a third dimension of coping. ${ }^{13-15} \mathrm{~A}$ great deal of research has established relation between personality traits and coping. For example, neuroticism to emotion-focused coping; optimism, selfesteem, and internal control beliefs to problem-focused forms of coping. ${ }^{16-18}$ Connor-Smith and Flachsbart's ${ }^{19}$ review illustrates a more complex set of relationships that show extraversion and conscientiousness personality traits to be associated with problem solving and cognitive restructuring coping and neuroticism demonstrated a greater association with such strategies as wishful thinking, withdrawal, and other forms of emotion-focused coping that are more avoidance directed.

Considering the various factors affecting the patients' ways of coping with stress, the present study aims to determine if there is any difference between coping strategies used by the two study groups and also how it effects on their psychological wellbeing.

\section{Aims and Consenting}

To assess and compare ways of coping with stress and psychological wellbeing of two groups of patient i.e. concealed group and unconcealed group of cancer patients visiting radiotherapy department, RIMS after taking informed consent.

\section{AIM}

The main goal is to compare ways of coping with stress and psychological wellbeing between patients who do not know about their diagnosis (Concealed group) and who know about their diagnosis (Unconcealed group).

\section{Inclusion and Exclusion Criteria \\ Inclusion}

1. Age between 20 years and 70 years.

2. Both male and female.

3. Diagnosed cancer patients getting treatment from Radiotherapy Department, RIMS.

\section{Exclusion}

1. Patients below 20 years and above 70 years.

2. Patients with mental retardation and past history of any major mental illness.

\section{Informed Consent}

Verbal informed consent was taken from each patient after full explanation of the aims and objectives of the study.

\section{MATERIAL AND METHODS}

A total of seventy six (76) cancer patients visiting Department of Radiotherapy, Regional Institute of Medical Sciences (RIMS), Imphal, during February 2014 to December 2014 were enrolled in this study. The total patients were divided into two groups of equal number i.e. 36 each for concealed and unconcealed groups and both the groups were administered the semi-structured questionnaire, Ways of Coping (Folkman S and Lazarus RS, 1985) and The Psychological Wellbeing Index (Dupuy, 1984) and the data were analysed using SPSS version 20.0 and the details of the questionnaires used are ways of coping questionnaire is developed by Folkman S and Lazarus RS in 1980 and revised in $1985 .{ }^{20}$ The present study used the revised version of the scale. It is a 66-item questionnaire containing a wide range of thoughts and acts that people use to deal with the internal and/or external demands of specific stressful encounters. The items are sub-grouped into eight (8) categories i.e. 1. Confrontive coping, 2. Distancing, 3. Selfcontrolling, 4. Seeking social support, 5. Accepting responsibility, 6. Escape-Avoidance, 7. Planful problemsolving, 8. Positive reappraisal. The items can be answered on a Likert scale with four (4) response categories- not used (0), used somewhat (1), used quite a bit (2), used a great deal (3). The raw score for each item on the eight subcategories in the scale are added to get a total score. Then, the relative score is calculated. High raw score or relative score indicates that the person often used the behaviours described by that scale in coping with the stressful event.

The psychological wellbeing index was developed by Dupuy (1984) ${ }^{21}$ contains 22 items divided into six dimensions: anxiety, depression, positive mood, vitality, self-control, and general health. The items can be answered on a Likert scale with six response categories classified according to the degree, intensity, or frequency of items in the last week. The total score is calculated from dimensional scores with categories created as such: ranging from 0 to 60 represents a serious discomfort, from 61 to 72 is a moderate malaise, and from 73 to 110 is a positive welfare. The reliability or internal consistency of the subjective wellbeing index is 0.9 and each dimension scored between 0.56 and 0.88 .

\section{Statistics}

Purposive method of sampling was applied in the present study and all data were analysed by using SPSS Version 20.0. Descriptive statistics summarised the continuous variables as frequencies and percentages for categorical, mean, and standard deviation. Independent samples t-test was used to compare categorical variables, ways of coping, and psychological wellbeing schedule score between the two groups. A value of $\mathrm{p}<0.05$ was considered as significant. 


\section{RESULTS}

\begin{tabular}{|c|c|c|c|c|}
\hline \multirow{2}{*}{$\begin{array}{l}\text { Characteristics } \\
\text { Patients }(\mathrm{N}=76)\end{array}$} & \multicolumn{2}{|c|}{ Concealed } & \multicolumn{2}{|c|}{ Unconcealed } \\
\hline & $\mathrm{N}=38$ & N\% & $\mathrm{N}=38$ & N\% \\
\hline $\begin{array}{l}\text { Gender: } \\
\text { Male } \\
\text { Female }\end{array}$ & $\begin{array}{l}16 \\
22 \\
\end{array}$ & $\begin{array}{l}42 \\
58 \\
\end{array}$ & $\begin{array}{l}21 \\
17 \\
\end{array}$ & $\begin{array}{l}55 \\
45 \\
\end{array}$ \\
\hline $\begin{array}{l}\text { Age Range: } \\
20-30 \\
30-40 \\
40-50 \\
50-60 \\
60-70\end{array}$ & $\begin{array}{l}3 \\
1 \\
7 \\
7 \\
20 \\
\end{array}$ & $\begin{array}{l}8 \\
3 \\
18 \\
18 \\
53\end{array}$ & $\begin{array}{l}4 \\
2 \\
10 \\
14 \\
8 \\
\end{array}$ & $\begin{array}{l}11 \\
5 \\
26 \\
37 \\
21 \\
\end{array}$ \\
\hline $\begin{array}{l}\text { Marital Status: } \\
\text { Married } \\
\text { Single (Widowed, divorced, Unmarried) }\end{array}$ & $\begin{array}{l}30 \\
8\end{array}$ & $\begin{array}{l}79 \\
21\end{array}$ & $\begin{array}{l}35 \\
3\end{array}$ & $\begin{array}{l}92 \\
8\end{array}$ \\
\hline $\begin{array}{l}\text { Education: } \\
\text { Illiterate } \\
\text { High school } \\
\text { University } \\
\end{array}$ & $\begin{array}{l}10 \\
11 \\
17 \\
\end{array}$ & $\begin{array}{l}18 \\
17 \\
3 \\
\end{array}$ & $\begin{array}{l}26 \\
29 \\
45\end{array}$ & $\begin{array}{l}47 \\
45 \\
8\end{array}$ \\
\hline $\begin{array}{l}\text { Occupation: } \\
\text { Housewife } \\
\text { Government employee } \\
\text { Self-employed }\end{array}$ & $\begin{array}{l}14 \\
5 \\
19 \\
\end{array}$ & $\begin{array}{l}37 \\
13 \\
50 \\
\end{array}$ & $\begin{array}{l}9 \\
10 \\
19 \\
\end{array}$ & $\begin{array}{l}24 \\
26 \\
50\end{array}$ \\
\hline $\begin{array}{l}\text { Monthly Income in Indian Rupee: } \\
<10,000 \\
10,000-20,000 \\
20,000 \text { and above }\end{array}$ & $\begin{array}{l}22 \\
12 \\
4\end{array}$ & $\begin{array}{l}58 \\
32 \\
10 \\
\end{array}$ & $\begin{array}{l}17 \\
16 \\
5 \\
\end{array}$ & $\begin{array}{l}45 \\
42 \\
13 \\
\end{array}$ \\
\hline $\begin{array}{l}\text { Family Type: } \\
\text { Nuclear } \\
\text { Joint }\end{array}$ & $\begin{array}{l}7 \\
31 \\
\end{array}$ & $\begin{array}{l}18 \\
82 \\
\end{array}$ & $\begin{array}{l}14 \\
24 \\
\end{array}$ & $\begin{array}{l}37 \\
63 \\
\end{array}$ \\
\hline $\begin{array}{l}\text { Duration of Illness: } \\
<1 \text { year } \\
1-2 \text { years } \\
>2 \text { years } \\
\end{array}$ & $\begin{array}{l}18 \\
13 \\
7 \\
\end{array}$ & $\begin{array}{l}47 \\
34 \\
19 \\
\end{array}$ & $\begin{array}{l}12 \\
21 \\
5\end{array}$ & $\begin{array}{l}32 \\
55 \\
13\end{array}$ \\
\hline
\end{tabular}

Table No.1 shows the socio-demographic profile of the two study groups i.e. the concealed group and the unconcealed group. In both the groups, sample is dominated by female patients (Concealed 22, 58\% and unconcealed 17, 45\%). Maximum and minimum no. of cases for concealed group in terms age are from 60-70 $(20,53 \%)$ and $30-40(1,3 \%)$ respectively and for unconcealed group, maximum and minimum cases in terms age belong to 50-60 (14,37\%) and 30-40 (2, 5\%), respectively. Further, maximum no. of cases in both the groups is married, self-employed, earns below Rs. 10,000 , and lives in a joint family. No. of patients educated up to university level is the minimum no. of cases in concealed group while it is the maximum no. of cases in unconcealed group. Based on duration of illness, maximum no. of cases in concealed and unconcealed groups belonged to the category of $<1$ year $(18,47 \%)$ and $1-2$ years $(21,55 \%)$ respectively.

\begin{tabular}{|c|c|c|c|}
\hline Ways of Coping: & $\begin{array}{c}\text { Concealed } \\
\text { Mean } \pm \text { SD }\end{array}$ & $\begin{array}{c}\text { Unconcealed } \\
\text { Mean } \pm \text { SD }\end{array}$ & $\begin{array}{c}\text { P Value } \\
\mathbf{N}=76\end{array}$ \\
\hline Confronting & $10.82 \pm 3.61$ & $10.92 \pm 2.83$ & .340 \\
\hline Distancing & $13.06 \pm 4.03$ & $14.00 \pm 3.44$ & .928 \\
\hline Self-control & $12.06 \pm 2.81$ & $11.86 \pm 2.98$ & .808 \\
\hline Seeking social support & $16.83 \pm 4.00$ & $17.49 \pm 4.36$ & .868 \\
\hline Accepting responsibility & $11.11 \pm 4.20$ & $10.00 \pm 3.74$ & .692 \\
\hline Escape-avoidance & $11.23 \pm 3.36$ & $10.90 \pm 3.58$ & .941 \\
\hline Planful problem solving & $13.25 \pm 3.54$ & $12.69 \pm 2.58$ & .106 \\
\hline Positive reappraisal & $11.37 \pm 2.65$ & $11.83 \pm 3.21$ & .390 \\
\hline
\end{tabular}

$\mathrm{N}=$ number of participant, $\mathrm{SD}=$ standard deviation. 


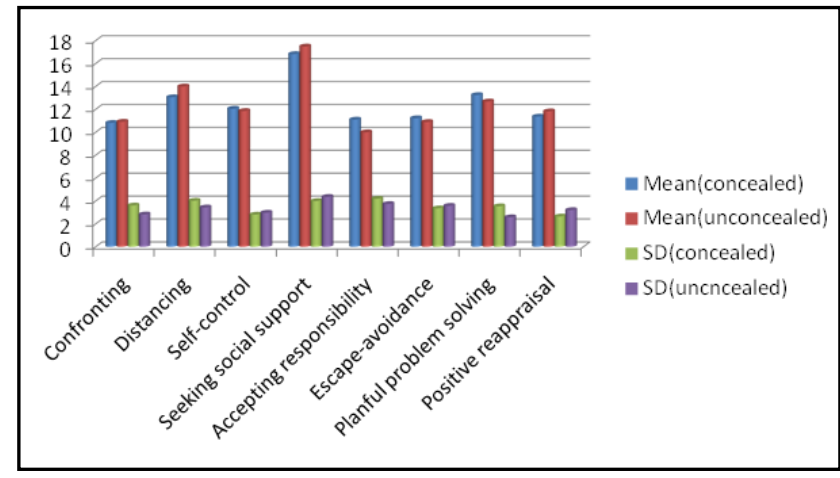

Fig. 1: Ways of Coping of Concealed and Unconcealed Groups
The comparison between the two study groups i.e. the concealed and unconcealed groups on their ways of coping is shown in table no. 2 and fig. 1 . The study finds no significant difference between concealed and unconcealed groups on their ways of coping with stress. The $p$-values for the subscales of the two groups are Confronting (.340), Distancing (.928), Self-control (.808), Seeking social support (.868), Accepting responsibility (.692), Escape-avoidance (.941), Planful problem solving (.106), and Positive reappraisal (.390).

\begin{tabular}{|c|c|c|c|}
\hline Psychological wellbeing Schedule & $\begin{array}{c}\text { Concealed } \\
\text { Mean } \pm \text { SD }\end{array}$ & $\begin{array}{c}\text { Unconcealed } \\
\text { Mean } \pm \text { SD }\end{array}$ & $\begin{array}{c}\text { P value } \\
\mathbf{N}=76\end{array}$ \\
\hline Anxiety & $62.2 \pm 16.8$ & $59.6 \pm 19.4$ & .513 \\
\hline Depressed mood & $59.8 \pm 25.3$ & $59.4 \pm 26.9$ & .700 \\
\hline +ve well being & $49.7 \pm 18.9$ & $52.1 \pm 20.1$ & .429 \\
\hline Self-control & $69.3 \pm 16.5$ & $70.7 \pm 15.5$ & .571 \\
\hline General health & $44.8 \pm 20.3$ & $47.9 \pm 20.3$ & .947 \\
\hline Vitality & $53.2 \pm 19.7$ & $50.2 \pm 20.7$ & .877 \\
\hline Global score & $56.4 \pm 17.7$ & $56.9 \pm 16.6$ & .671 \\
\hline \multicolumn{2}{|l|}{} \\
\hline
\end{tabular}

$\mathrm{N}=$ number of participant, $\mathrm{SD}=$ standard deviation

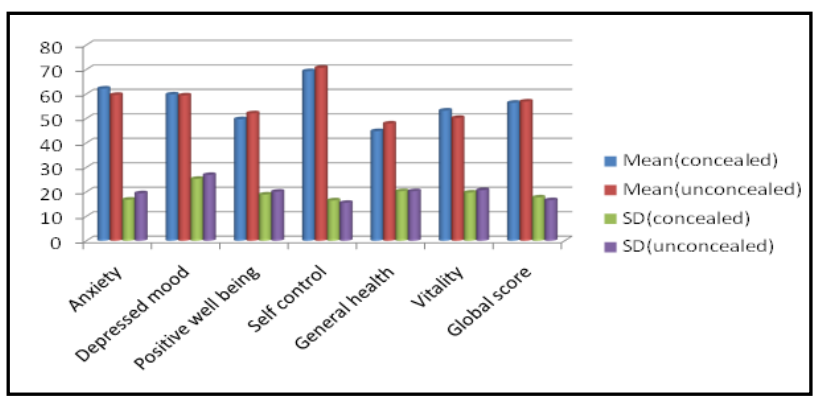

Fig. 2: Psychological Wellbeing of the Concealed and Unconcealed Groups

Table no. 3 and fig. 2 shows that there is no significant difference between the two study groups in terms of their psychological wellbeing. The p-values for the subscales of psychological wellbeing schedule of the two groups are Anxiety (.513), Depressed mood (.700), positive wellbeing (.429), Self-control (.571), General health (.947), Vitality (.877), Global score (.671).

\section{DISCUSSION}

The study sample consisted of 76 cancer diagnosed patients undergoing treatment at Department of Radiotherapy, RIMS Imphal. This study compared two groups of patient i.e. concealed group and unconcealed group. The number of patients in both the groups are $38(50 \%)$ each. The number of male in concealed and unconcealed groups are $16(42 \%)$ and $21(55 \%)$ respectively. The number of female in concealed and unconcealed groups are $22(58 \%)$ and 17 (45\%) respectively. Distribution based on age groups of the concealed group patients ranges from $20-30(3,8 \%), 30-40(1,3 \%), 40-50(7$, $18 \%), 50-60(7,18 \%)$, and $60-70(20,53 \%)$ and for the unconcealed group patients, age distribution are 20-30 (4, $11 \%), 30-40$ (2, 5\%), 40-50 (10, 26\%), 50-60 (14, 37\%), and $60-70(8,21 \%)$. In both the groups, no. of married patients are more i.e. $30(79 \%)$ for concealed and 35 (92\%) for unconcealed than single (Widowed, divorced, unmarried) patients- $8(21 \%)$ and $3(8 \%)$ for concealed and unconcealed groups respectively. Most of the patients in the concealed group are illiterate $18(47 \%)$ followed by patients educated up to high school 17 (45\%) and university level 3 (8\%). On contrary in unconcealed groups, most of the patients are educated up to university level 17 (45\%) followed by high school 11 (29\%) and illiterate 10 (26\%). Occupation wise distribution shows that most of the patients are self-employed $19(50 \%)$ followed by housewife $14(37 \%)$ and government employee $5(13 \%)$ in concealed group and most of the patients in unconcealed group are also self-employed $19(50 \%)$ followed by government employee 10 (26\%) and housewife 9 (24\%). 31 (82\%) of patients in concealed group live in a joint family and rest 7 (18\%) live in a nuclear family. In case of unconcealed group, 24 (63\%) of the patients live in a joint family and $14(37 \%)$ live in nuclear family. In the concealed group, patients based on duration of illness is high on $<1$ year $18(47 \%)$ and followed by $1-2$ years $13(34 \%)$ and $>2$ years $7(19 \%)$. In the unconcealed group, patients based on duration of illness is high on $1-2$ years $21(55 \%)$ and followed by $<1$ year $12(32 \%),>2$ years 5 (13\%). In a study gender, time since diagnosis, presence of metastatic disease, time in the support group, perceived group support, cognitive avoidance, and fatalism were unrelated to mood disturbance. ${ }^{22}$

Despite the differences in the backgrounds of the patients in the two study groups, comparison on their ways of coping with stress and psychological wellbeing shows no significant difference.

The $p$-values for the subscales of ways of coping are Confronting ( $p$ value $=.340)$, Distancing ( $p$ value $=.928)$, Selfcontrol ( $p$ value $=.808)$, Seeking social support ( $p$ value=.868), Accepting responsibility ( $p$ value $=.692)$, Escape avoidance $(p$ value $=.941$ ), Planful problem solving ( $p$ value $=.106$ ), Positive 
reappraisal ( $\mathrm{p}$ value=.390). Though there is no significant relationship between the two studies groups, coping strategies used by the concealed patients in descending order are: i. seeking social support $(16.83 \pm 4.00)$, ii. Planful problem solving (13.25 \pm 3.54$)$, iii. Distancing $(13.06 \pm 4.03)$, iv. Selfcontrol (12.06 \pm 2.81$)$, v. Positive reappraisal (11.37 \pm 2.65$)$, vi. Escape avoidance $(11.23 \pm 3.36)$, vii. Accepting responsibility $(11.11 \pm 4.20)$, viii. Confronting $(10.82 \pm 3.61)$ and for the unconcealed group's descending value of Mean \pm SD on the subscales of their ways of coping are i. Seeking social support $(17.49 \pm 4.36)$, ii. Distancing $(14.00 \pm 3.44)$, iii. Planful problem solving (12.69 \pm 2.58$)$, iv. Self-control $(11.86 \pm 2.98)$, v. Positive reappraisal $(11.83 \pm 3.21)$, vi. Confronting $(10.92 \pm 2.83)$, vii. Escape avoidance (10.90 \pm 3.58$)$, viii. Accepting responsibility $(10.00 \pm 3.74)$. This finding is in line with a descriptive study, which suggests that emotional support is most desired by patients and emotional support has the strongest associations with better adjustment. ${ }^{23}$ In another study done on 95 patients with Tis-T4 laryngeal cancer found that the most commonly used adjustment response at was fighting spirit and the use of adjustment responses was relatively stable overtime. ${ }^{24}$

There is no significant difference between the two groups in their psychological wellbeing. The p-values for the subscales of psychological wellbeing schedule of the two groups are Anxiety (.513), Depressed mood (.700), Positive wellbeing (.429), Self-control (.571), General health (.947), Vitality (.877), Global score (.671). The concealed group's descending order of Mean \pm SD on the subscales of psychological wellbeing schedule are i.e. Self-control $(69.3 \pm 16.5)$, ii. Anxiety (62.2 \pm 16.8$)$, iii. Depressed mood $(59.8 \pm 25.3)$, iv. Vitality (53.2 \pm 19.7$)$, v. Positive wellbeing $(49.7 \pm 18.9)$, vi. General health (44.8 \pm 20.3$)$, and Global score is $(56.4 \pm 17.7)$. The unconcealed group's descending order of Mean \pm SD on the subscales of psychological wellbeing schedule are i. Selfcontrol $(70.7 \pm 15.5)$, ii. Anxiety (59.6 \pm 19.4$)$, iii. Depressed mood (59.4 \pm 26.9$)$, iv. Positive wellbeing (52.1 \pm 20.1$)$, v. Vitality (50.2 \pm 20.7$)$, vi. General health (47.9 \pm 20.3$)$, and Global score is $(56.9 \pm 16.6)$. The present study finding of high self-control is in line with a study that found that cancer survivors exhibited resilient social wellbeing, spirituality, and personal growth. Moreover, age appeared to confer resiliency; older survivors were more likely than younger adults to show psychosocial functioning equivalent to their peers. ${ }^{9}$

\section{Limitation}

Patients from suffering from any type of cancer and at any stage of illness were included in the study sample. Another limitation is unequal proportion of married and unmarried sample.

\section{CONCLUSION}

The present study finds insignificant relationship between the two study groups on their ways of coping with stress and the psychological wellbeing. The insignificant difference between the two study groups might be due to the similarity of the illness syndrome as well as treatment effects experienced by the patients irrespective of their knowledge about the diagnosed disease. The presumed condition needs to be explored further.

\section{REFERENCES}

1. Carlson E, Bultz BD. Benefits of psychosocial oncology care: improved quality of life and medical cost offset. Health and Quality of Life Outcomes 2003;1(8):1-9.

2. Podmore EJ, Bingham LC, Roberts KM, et al. Routine assessment of social difficulties in cancer patients: are we opening Pandora's box? Support Care Cancer 2009;17:1425-32. doi: 10.1007/s00520-009-0690-7.

3. Smith $A B$, Wright $P$, Selby $P$, et al. Measuring social difficulties in routine patient-centred assessment: a rasch analysis of the social difficulties inventory. Quality of Life Research 2007;16(5):823-31. DOI: 10.1007/s11136-0079181-9.

4. Garcia-Viniegras C, Gonzalez I. La categoria bienestar psicologico, su relacion con otras categorias sociales. Revista Cubana de Medicina Integral 2000;16(6):586-92.

5. Lopez M, Torres G. Estudios sobre calidad de vida en pacientescon cancer en tratamiento de quimioterapia. Tesis de maestria, Pontificia Universidad Javeriana 2001.

6. Novoa-Gomez MM, Ballesteros BP. The role of the psychologist in an intensive care unit. Universitas Psychologica 2006;5(3):599-613.

7. Rodriguez-Marin J. Psicologia social de la salud. Madrid: Sintesis 1998.

8. Diener E, Oishi S, Lucas RE. Personality, culture, and subjective wellbeing: emotional and cognitive evaluations of life. Annual Review of Psychology 2003;54:403-25.

9. Costanzo ES, Ryff CD, Burton HS. Psychosocial adjustment among cancer survivors: findings from a national survey of health and wellbeing. Health Psychology 2009;28(2):147-56.

10. Lazarus RS, Folkman S. Stress, appraisal, and coping. New York: Springer Publishing Company 1984.

11. Claudia A, Ennbergj AN, Chill A, et al. Coping, psychosocial wellbeing, and anxiety in cancer patients at followup visits. Acta oncologica 1994;33(8):887-94.

12. Folkman S. Stress, coping, and hope. Psycho-Oncology 2010;19:901-8. DOI: 10.1002/pon.1836.

13. Roth S, Cohen LJ. Approach, avoidance, and coping with stress. Am Psychol 1986;41(7):813-9.

14. Carver CS, Scheier MF, Weintraub JK. Assessing coping strategies: a theoretically-based approach. J Pers Soc Psychol 1989;56(2):267-83.

15. Endler NS, Parker JD. Multidimensional assessment of coping: a critical evaluation. J Pers Soc Psychol 1990;58(5):844-54.

16. Hewitt PL, Flett GL. Personality traits and the coping process. In: Zeidner M, Endler NS, (Eds). Handbook of NY. John Wiley and Sons 1996:410-33.

17. Aspinwall LG, Taylor SE. Modeling cognitive adaptation: a longitudinal investigation of the impact of individual differences and coping on college adjustment and performance. Journal of Personality and Social Psychology 1992;63(6):989-1003.

18. Terry DJ. Coping resources and situational appraisals as predictors of coping behaviour. Personality and Individual Differences 1991;12(10):1031-47.

19. Connor-Smith JK, Flachsbart C. Relations between personality and coping: a meta-analysis. Journal of Personality and Social Psychology 2007;93(6):1080-107. 
20. Folkman S, Lazarus RS. Ways of coping questionnaire. Mind Garden, 1690 Woodside Road, Suite 202, Redwood City, CA 94061 USA. www.mindgarden.com

21. Chassany O, Dimenas E, Dubois D, et al. The Psychological General Well-Being Index (PGWBI) user manual with an historical Appendix, Harold Dupuy Copyright(C) MAPI Research Institute 2004. http://www.mapi-trust.org. http://www.mapi-institute.com

22. Cordova MJ, Giese-Davis J, Golant M, et al. Mood disturbance in community cancer support groups: the role of emotional suppression and fighting spirit. Journal of Psychosomatic Research 2003;55(5):461-7.
23. Helgeson V, Cohen S. Social support and adjustment to cancer: reconciling descriptive, correlational, and intervention research. Health Psychology 1996;15(2): 135-48.

24. Johansson M, Ryden A, Finizia C. Mental adjustment to cancer and its relation to anxiety, depression, HRQL, and survival in patients with laryngeal cancer - a longitudinal study. BMC Cancer 2011;11:283.

http://www.biomedcentral.com/1471-2407/11/283. 